\title{
Europeanization, Territorial Subsidiarity and Welfare Reform
}

\author{
LUIS MORENO \\ Spanish National Research Council (CSIC), Madrid, Spain
}

ABSTRACT Europeanization can be regarded as a process that finds expression in the gradual redefinition of state sovereignty and the development of supranational common institutions (e.g. Agreement of Schengen, Court of Justice, Euro currency). In parallel, territorial subsidiarity seeks to provide for a greater sub-state say in areas of social policy making, often linked to cultural or identity considerations. This article deals with welfare development in the European social model in contemporary times. While a paradigm shift in macro-economic policies has allowed for monetary centralization and a growing matching of EU internal 'open' markets, the quest for the decentralization of welfare programmes has also aimed at meeting demands for policy innovation and a more effective management. Allegedly, welfare provision by sub-state diversity may affect collective solidarity and redistribution. The emergence of new social risks and the role played by the mesogovernments in welfare reform in Europe are also subject to analysis and discussion in this article.

KEY WORDS: Decentralization, Europe's Social Model, regions, welfare

\section{Introduction}

The unfolding of structures of governance in the European Union (EU) is taking place by means of formalizing interactions-directly and indirectly-among the EU's twenty-seven member states. These interactions mainly affect policy networks which have been traditionally confined to nation-state policy arenas. An emerging new layer of supranational government and an internal all-round political concurrence are processes well under way. As a multi-level political and institutional framework, the EU can be seen as a compound of policy processes.

Europeanization therefore implies that national, regional and local policies are shaped by factors that lie beyond the member states. Europeanization is a concept with economic, political and social aspects, and involves countries sharing a similar historical background and embracing values of democracy and egalitarian human rights. The concept is, however, far from precise and clear-cut and is subject to several interpretations. The peoples of the EU have, to some extent, internalized European institutions, albeit rather loosely and gradually. The European Court of Justice and the Schengen Agreement, as well as common policies such as the establishment of the Euro, the economic criteria set by the Maastricht Treaty or policy programmes developed under the OMC (Open Method of Co-ordination) can be regarded as steps towards supra-state Europeanization. However, the constitution of a United States of Europe ought not to be regarded as the necessary outcome of this process of Europeanization. The neo-functionalist school of thought has generally adopted the view that universal progress requires integration, which is made equal to cultural assimilation and single identity formation, along the lines of the American 'melting-pot'. In parallel with the process of Europeanization, the principle of subsidiarity provides for decisions to be taken at EU level only if local, regional or national democratic institutions cannot perform better. In other words, the preferred locus for decision making is that which is closer to the citizen, and as local as possible. This interpretation is not shared by some political elites of the EU member states who have often interpreted the subsidiarity principle as a safeguard for the preservation of traditional national sovereignty (the UK is the most notorious example but there are others as well). Both bottom- 
up supra-nationalization and top-down decentralization have allowed a considerable extension of what may be called a European cosmopolitan localism (Moreno, 2005). This is seen when societal interests aim both at developing a sense of local community and also of participating on the international scene. In this way both the particular and the general come together. In a European and global perspective, the harmonization of economic development has gone hand in hand with the decentralization of political institutions and the regionalization of welfare development. The role of sub-state1 territories in these processes, however, has been largely neglected. Already in 2001, the White Paper on European Governance (CEC, 2001) stated that the national governments of the member states were not involving the local and regional 'actors' in an appropriate manner in the preparation of their positions on EU policies and, consequently, were not facilitating democratic accountability at those levels of government. Illustrative of this lack of political impulse is the case of the regions with legislative powers. In 2002 about half of the EU-15 regions were 'partner regions', or regions with legislative powers (in almost half of the member states), and were regarded as not being genuinely accountable to their own citizens (Committee of the Regions, 2002). In June 2007, the members of the Committee of the Regions from 74 regions with legislative powers in eight EU member states made a declaration claiming for more proximity, more involvement of regions and local authorities and for the respect of the principles of subsidiarity and proportionality (Regleg, 2007). Welfare has remained largely a national government function, funded by compulsory contributions or tax-financed schemes of social protection. However, the political salience of sub-state regions and regional policy making in the welfare realm has recently begun to draw attention to the interrelationship of both fields of research: territory and welfare (McEwen and Moreno, 2005). Not so long ago, ideas, interests and institutions related to welfare and to spatial developments were frequently regarded as contradictory or even incompatible with each other. Generally speaking, territorial politics literature has tended to neglect the social dimension, while research on welfare has taken the unitary nation-state for granted. Regional actors, meso-governments and local authorities are now seen as important not just for culture and identity politics but are increasingly regarded as optimal welfare policy providers. This is a result of the interaction of the processes of bottom-up globalization and top-down devolution of powers. Welfare decentralization, however, has also been criticized on the grounds that it can exacerbate inequalities and jeopardize collective solidarity. All these developments might have modified, to some extent, the tenets and configurations characteristic of European welfare states. Is today's European social model based upon the same cognitive and normative principles that were dominant several decades ago? Have the views of actors been modified substantially on the role of the European welfare states? Is there a growing convergence or divergence among national welfare approaches to reform? Can we expect the development of supranational European institutions in the field of social policy and/or a further Europeanization of national welfare policies? These are questions, regarding both the functional and territorial aspects of social life, that need to be scrutinized in order to lend evidence to claims of paradigm shifts and mutations within the broad model of social Europe. The two subsequent sections of this article examine the link between economic paradigm shifts and welfare reform in Europe. The emergence of 'new social risks' and the recipes to meet these new risks seem to indicate a convergence of responses in the various European welfare regimes. In general, most EU countries are influenced by the 'liberal' re-commodifying approach to social protection. This, however, should not be regarded simply as the 'Americanization' of welfare. In fact, there is a widespread belief in most EU countries that the European social model provides collective unity and identity, in contrast to other systems, such as that in the USA, where possessive individualism is a distinctive tenet of welfare provision, or 
South-east Asia's 'social dumping' model of economic development. After discussing the territoriality of welfare solidarity, an examination of the increasing role played by the sub-state levels of European governance will be made in the latter part of this article.

\section{Economic Paradigm Shift and Welfare Reform in Europe}

In general terms, paradigms suggest new approaches to empirical evidence, new problems for solution and sometimes, but not necessarily, new explanations for phenomena which cannot be understood through other paradigms. In policy terms, a paradigm is concerned with the manner political and social actors approach key issues and seek to resolve them. Paradigms, value systems and referentiels provide normative and cognitive elements, which shape principles and actions adopted by actors within the same frame (Kuhn, 1970; Jobert and Muller, 1987; Hall, 1993; Surel, 2000). It has been argued that a significant paradigm transformation has occurred concerning the European welfare state, which correlates changes in economic policies (most notably, from Keynesianism to Monetarism) (Moreno and Palier, 2005). Has welfare development in Europe, as a consequence, evolved into a mere surrogate of economic ideas, interests and institutions? Certainly there are a number of new features which may have given way to what can be regarded as a distinct post-welfare state model (Loughlin, 2004). Let us remind ourselves that during the Trentes Glorieuses, or 'Golden Age' of welfare capitalism (1945-75), West European systems of social protection were based upon the assumption of full employment and on the complementary roles of mother and father within the nuclear family and, in particular, of women's unpaid work within households (Esping-Andersen, 1990; Lewis, 1997). A combination of social policies, Keynesianism, Taylorism and female segregation facilitated a sustained economic growth and the generalization of a kind of 'affluent worker'. The outcome of these factors translated into two main types of welfare state: the Keynesian-Beveridgean and the Keynesian-Bismarckian welfare states. In both types of welfare state, national governments managed economies with a relatively high degree of autonomy. They were able to provide social provision for needs which market and family did not meet. The tax consequences of such provision were legitimated upon political coalitions of working- and middle-class groups (Flora, 1986/87). The effects of the oil crises in $1973-74$ and 1978- 79 revealed the increasing openness and interdependence of European economies, and altered a scenario of prosperity and abundant stable male employment. Nevertheless, the Golden Age evolved into a Silver Age of the welfare state showing limitations but also a high degree of resilience in resisting pressures of a diverse nature (Taylor-Gooby, 2002). During the 1980s and 1990s, a neo-liberal ideological offensive challenged the tenets and legitimacy upon which welfare states had previously developed. Its discourse elaborated on the effect that processes of international competition and industrial transformations had had on the national labour markets. In parallel, deep structural modifications had taken place as a consequence of the ageing of the population, the increasing participation of women in the formal labour market and the rearrangements that had occurred within households as producers and distributors of welfare. In sum, fiscal crises and the erosion of the ideological consensus which gave way to the 'Mid-century Consensus' had conditioned the recasting of welfare states in Europe (Crouch, 1999; Ferrera and Rhodes, 2000; Esping-Andersen et al., 2002). Economic reforms have also led to monetary centralization and a growing harmonization of single-market policies in the European Union, and EU member states have faced and implemented policies of a similar nature. Those countries which attempted to exercise their nominal state sovereignty against the tide of the new economic policies were penalized heavily. Failure of the programmes for indicative planning implemented by the first Mitterrand government in the early 1980s illustrated the 
'persuasiveness' of the new economic neo-classical and supply-side paradigm embraced by neighbouring and competing countries. This episode illustrated that national economic 'sovereignty' was very limited in manoeuvres to promote the previous Keynesian demand-side approach (Camilleri and Falk, 1992; Schmidt, 1995; Strange, 1995). In the light of the economic changes that have occurred in Europe over the last 30 years, can we conclude that European welfare has substantially changed even if their outer forms remain as they were before? In trying to respond to such a question it should be pointed out that all three political, economic and social dimensions are simultaneously present in a paradigm, even if we agree that one of them is usually dominant or hegemonic. Alternatively, different dimensions, (economic, political and social) could be considered on their own merits. A paradigm shift would result from the interaction of all three of them. If we were to take into account the latter view, the statement that social welfare in Europe has been over-determined by economics ought to be qualified (Jessop, 2002). Such interpretation is based upon the stable high levels of public social expenditure and popular support for welfare in Europe (Svallfors and Taylor-Gooby, 1999; Bonoli, 2000; Kuhnle, 2000; Pierson, 2001; van Oorschot, 2002). An important conceptual distinction may be drawn between (a) objective economic and social elements that influence the context in which the politics of welfare reform operates; and (b) the subjective level of the understanding of those issues by those actors involved in interpreting popular perceptions and influencing reforms. The latter dimension influences not only processes of policy learning and transfer. It also affects opportunities for coalition-building and the extent to which policy reform is to be understood as pursuing a new direction-based on new values and objectives-or as modification of existing policy directions. Such an 'objective - subjective' distinction is useful in analysing the emergence of new social risks-alongside traditional social needs-across European welfare states (Taylor-Gooby, 2005). With the extension of the criteria for 'open' market competition stimulated by economic globalization, subsequent deregulation and market flexibility have allowed for the extension of a general sense of uncertainty and the emergence of new social risks. These are associated with the transition to a post-industrial (post-Fordist) society (Esping-Andersen, 1999) and relate to four main elements: (1) higher participation of women in the formal labour market; (2) an increase in the numbers of frail and dependent elderly people; (3) the rise of social exclusion for workers with poor education; and (4) the expansion of private services and the de-regulation of their public counterparts. As a consequence, vulnerable groups are likely to experience new needs in four broad areas: (1) balancing paid work and family responsibilities (especially childcare); (2) being called on for care of a frail elderly relative, or becoming frail and lacking family support; lacking the skills necessary to gain access to an adequately paid and secure job; (3) having skills and training that become obsolete and being unable to upgrade them through life-long learning; and (4) using private provision that supplies an insecure or inadequate pension or unsatisfactory services (Bonoli, 2005). The answer to the question of whether new social risks would induce new welfare rearrangements and how they could be reconciled with old 'core' commitments for social provision is still to be articulated by European actors in the various contexts of European governance. Until now, new social risks do not seem to add up to a new paradigm of welfare, but ought rather to be regarded as a modification that will generate new political discourses testing economic reforms which favour the introduction of a more flexible and de-regulated European social model. Despite the diversity of its institutional forms and manifestations in the EU's mature welfare states, the European social model can be still identified as one based upon collective solidarity and as the result of institutional patterns of social conflict and cooperation in the Old Continent. The article now turns to a brief 
examination of its nature and to a discussion of some of the territorial challenges for its adaptation to changing economic, political and social scenarios.

\section{Europe's Social Model, Decentralization and Solidarity}

During the twentieth century the rise of the welfare state-a European 'invention' - allowed provision for the basic needs of 'the people', by means of income security, health care, housing and education. There is a widespread belief that the 'European social model' provides collective unity and identity to most EU countries, in contrast to other systems, (individualism of welfare provision in the USA, or 'social dumping' in South-east Asia, for example). The articulation of 'floors' or 'safety nets' of legal rights and material resources for citizens to participate actively in society can be seen as a common primary concern of the European countries. Accordingly, the fight against poverty and social exclusion plays a central role in the European social model. The EU countries share a common perspective on social risks coverage and the promotion of egalitarian social citizenship. In functional terms, EU member states have embraced new economic policies of a similar nature. As stated earlier, those countries, which attempted to exercise their nominal state sovereignty against the tide of the new economic policies, were penalized heavily. Less attention has been generally paid to the territorial dimension of welfare and, in particular, to the growing input made by sub-state institutions and actors for welfare development and the alleged threats of exacerbating territorial inequalities within a model based upon collective solidarity. One result of intra-state historical variations, often reflected in different party systems, channels of elite representation or interest articulation, is that decentralization has become a major embedding factor in contemporary political life in Europe. Decentralization in some countries (for example, Belgium, Italy or Spain) affects the very 'core' of traditional social policies. In these countries, health care, for instance, has been decentralized, allowing the establishment of regional systems of health provision (McEwen and Moreno, 2005). EU institutions, particularly the Commission and the Parliament, have encouraged multilateral co-operation on the assumption that national states would be less 'sovereign' than they have been up until now. Increasingly, sub-state governments and local authorities do not require the rationalizing intervention of central bureaucracies and elites, and can activate policies of industrial relocation or attraction of foreign capitals without the role of intermediaries from the central state. By means of local incentives, urban re-development plans, or favouring corporatist agreements with trade unions and industrialists, regional governments and metropolitan authorities can have direct negotiations with the transnational corporations involved (Rhodes, 1996; Moreno, 2003). Sub-state governments do not exist in isolation from the new international order. They are subject to the same socio-demographic pressures and the necessity of a greater interrelationship with institutions and actors beyond their boundaries (Jones, 1995; Keating, 1998). This may constrain their capacity to generate social solidarity and reinforce territorial loyalties through the distribution of social transfers and services. Critics of the de-structuring of the old order have suggested that globalization, decentralization and the increasing role of sub-state governments may bring about two major drawbacks to welfare development. (1) Sub-state governments may be more sensitive to pressures from the business community for increased flexibility, lower taxation and lower public spending. Individually, sub-state societies appear more vulnerable to the threat of dis-investment in an era when capital is increasingly mobile, and when even a single corporate relocation can devastate an entire community (Piven, 1995). (2) Sub-state governments may be tempted in an increasingly competitive international arena to offer 'too' generous conditions for capital investment or industrial relocation. By engaging themselves in a 'race to the bottom', social 
rights may be restricted, making welfare retrenchment inevitable. Viewed from this angle, decentralization would render social citizenship rights somewhat precarious (Mishra, 1999). It follows from such analyses that national governments should take on redistribution, while substate governments should be in charge of developmental functions and policy provision. However, no consistent empirical findings lend support for a 'positive sum' arrangement, with the allocation of the function of redistribution to the national level and those concerning the operationalization of welfare policies to the regional level. Politicians in either national or regional governments make choices so as to maximize their own benefits. This fact greatly explains why members of both layers of government are reluctant to tax their constituents in order to allow less-favoured citizens to prosper, something which makes redistribution difficult (Peterson, 1995). Both politicians and decision makers at state and sub-state levels may become 'credit-claimers' or 'blame-avoiders', depending upon their situational logic and political strategies. Furthermore, what is economically efficient may not be politically possible or sustainable.2 Thus, the political impacts on national and regional bureaucracies in the implementation process must both be taken into account. Likewise, national and regional politicians seek credit for their activities and they do so regardless of economic and rational arguments. The form of decentralization is an important area for analysis in assessing redistribution and social policy outcomes. Some findings point to the fact that countries in which responsibility for spending is decentralized, but responsibility for revenueraising is centralized, tend to spend more than other countries, other things being equal. By contrast, in countries where both revenue-raising and welfare spending are decentralized, expenditure levels appear lower (Rodden, 2003). Concerns over the 'race to the bottom' or, conversely, of sub-state communities becoming welfare 'magnets', have generally been overstated. While politicians may choose to believe that generous benefits will attract welfare beneficiaries from other sub-state territories, there is little evidence to support such claims. Even in a federal country, such as the USA-where there is a much greater geographical mobility than in Europe - there is little empirical evidence to suggest that 'welfare tourism' or 'voting with their feet' actually takes place (Weissert and Weissert, 2002; Berry et al., 2003). The debate on whether decentralization constrains redistribution and solidarity is an unfinished one. There is a large cross-national literature which uses multivariate analysis to understand the factors that influence levels of social spending (Hicks and Swank, 1992; Huber and Stephens, 2001). This literature has a long-standing trajectory (Cameron, 1978) and has regularly concluded that federalism and/or decentralization constrains the expansion of the welfare state. Further arguments point to the contention that it can have more powerful negative effects than any other institutional variable; greater than factors such as the level of corporatism in decision making, the nature of the electoral system or a presidential system of government (Swank, 2002). Redistribution may also be affected by the state's internal composition. It has been argued that the degree of redistribution is more limited in countries that are culturally heterogeneous or that have high levels of immigration. It has also been suggested that public policies designed to recognize and accommodate internal diversity are detrimental to the robustness of the welfare state, with numerous consequences. They may have: (1) a crowdingout effect, diverting energy, money and time from redistribution to recognition; (2) a corroding effect, eroding trust and solidarity amongst citizens; or (3) a misdiagnosis effect, with 'culturalist' solutions shifting attention from the 'real problem' of class inequalities. However, the linkage between welfare retrenchment and policies of accommodation and recognition is not empirically sustained. In fact, countries that have implemented far-reaching policies of accommodation and recognition tend to demonstrate a greater positive correlation between social spending and redistribution (Banting and Kymlicka, 2003). Modernizing strategies by 
sub-state levels of government have found in the principle of European subsidiarity a renewed impulse for the running of public affairs, and new opportunities for policy experimentation. There is certainly a case for sub-state units to become 'laboratories of democracy'. It has been claimed that the payoff from innovation exceeds the advantages of uniformity: the greater the need for innovation (for example, a 'new' problem or solution), the greater is the rationale for that function to be provided by the sub-state government (Donahue, 1997).

\section{Concluding Remarks}

Despite the political anti-climax brought about by the failure of the drafted 2005 European Constitution to be approved by EU member states, Europeanization continues its process of system-building and multi-level governance. Political developments, however, do not necessarily point towards a 'command-and-control' model of European vertical welfare provision. The polycentric nature of Europeanization and the compound structuring of intergovernmental governance do not lead to the institutionalization of a centralized EU. Rather, Europeanization confronts a gradual and necessarily 'slow' process of accommodating cultural, historical and political diversity within the Old Continent while respecting the principles of democratic accountability and territorial subsidiarity. Consequential to their profound embedding in the development of the modern nation-state, European welfare systems face difficult dilemmas in the transition towards new multi-level configurations. At present, a fully fledged articulation of social citizenship in the EU framework seems unrealistic, despite its desirability (Ferrera, 2005). However, national, regional and local governments can work together with EU institutions in multilateral agreements, allowing mutual collaborations in the three main stages of policy process (planning, decision making and monitoring). Frameworks of solidarity, such as those provided by state systems of social insurance, or increasingly those affected by European directives, will continue to play a crucial role. However, sensitive areas of citizens' concern, where more efficient policy provision is plausible by means of more effective development of community-orientated services, are increasingly important. Of particular relevance are those concerned with the weaving of 'safety nets' to combat poverty and social exclusion, and with the development of social services for young children and for the frail elderly. Such areas of social intervention appear suitable to be run by elected sub-state levels of government, which can be accountable for the implementation of means-tested programmes, and for purposes of optimizing economies of scale. In this manner, the re-launching of programmes of social citizenship may also be articulated from 'below'.

\section{Acknowledgements}

The author has partly re-elaborated some texts previously co-authored with Nicola McEwen and Bruno Palier. As a member of both research teams, the author is also grateful to the WRAMSOC project ('Welfare Reform and the Management of the Societal Change', European FP5) and the NURSOPOB project ('New Social Risks and Welfare Policy Trajectories', Spanish National R\&D Plan, SEJ2005-06599), for making use of some of the findings produced during the period 2002-07. Thanks also go to John Loughlin and Javier Moreno for comments on an earlier version of this article. Responsibility for interpretations and views remain solely with the author.

\section{Notes}

1. Or 'sub-national', a term used by some authors in order to avoid confusion when referring to federations where the meso-level is constituted by 'states'. Certainly, 'state' and 'nation' are 
not synonymous concepts, as multinational and compound states can be comprised of several nations within their territories.

2. On analysing the effect of two federal grant programmes in the USA, Chubb (1985) found the exact opposite of what economists predicted. This was because the political factors affected the oversight and ultimately the overall spending.

\section{References}

Banting, Keith and Kymlicka, Will (2003), Do multiculturalism policies erode the welfare state. Paper presented at the Conference on New Challenges for Welfare State Research (ISA RC19), Toronto, 21-24 August.

Berry, William, Fording, Richard and Hanson, Russell (2003), Reassessing the "race to the bottom" in state welfare policy: resolving the conflict between individual level and aggregate research, Journal of Politics, Vol.65, No.2, pp.327-349.

Bonoli, Giuliano (2000), Public attitudes to social protection and political economy traditions in Western Europe, European Societies, Vol.2, No.4, pp.431- 453.

Bonoli, Giuliano (2005), The politics of the new social policies: providing coverage against new social risks in mature welfare, Policy \& Politics, Vol.33, No.3, pp.431-449.

Cameron, David (1978), The expansion of political economy: a comparative analysis, American Political Science Review, Vol.72, pp.1243-1261.

Camilleri, Joseph and Falk, Jim (1992), End of Sovereignty? The Politics of a Shrinking and Fragmenting World. Aldershot: Edward Elgar.

CEC (Commission of the European Communities) (2001), White Paper on European

Governance, $\operatorname{COM}(2001) 428$ final. Brussels: CEC. Available at http://eurlex.europa.eu/LexUriServ/site/en/ com/2001/com2001_0428en01.pdf] (accessed 25 August 2007).

Chubb, John (1985), The political economy of federalism, American Political Science Review, Vol.79, No.4, pp.994-1015. Committee of the Regions (2002), Contribution of the Committee of the Regions to the European Convention, CdR 127/2002. Brussels: Committee of the Regions.

Crouch, Colin (1999), Social Change in Western Europe. Oxford: Oxford University Press.

Donahue, John (1997), Disunited States. New York: Basic Books.

Esping-Andersen, Gøsta (1990), The Three Worlds of Welfare Capitalism. Cambridge: Polity Press.

Esping-Andersen, Gøsta (1999), Social Foundations of Post-industrial Economies. Oxford: Oxford University Press.

Esping-Andersen, Gøsta, with Gallie, Duncan, Hemerijck, Anton and Myles, John (2002), Why We Need a New Welfare State. Oxford: Oxford University Press.

Ferrera, Maurizio (2005), Beyond national social rights?, in Nicola McEwen and Luis Moreno (eds), The Territorial Politics of Welfare, pp.225-243. London/New York: Routledge. Ferrera, 
Maurizio and Rhodes, Martin (eds) (2000), Recasting European Welfare States. London: Frank Cass.

Flora, Peter (1986/87), Growth to Limits. The European Welfare States Since World War II (3 vols). Berlin: De Gruyter. Hall, Peter (1993), Policy Paradigms, Social Learning, and the State: The Case of Economic Policymaking in Britain, Comparative Politics, Vol.25, No.3, pp.275- 296.

Hicks, Alexander and Swank, Duane (1992), Political institutions and Welfare Spending in Industrialized Countries, 1960-82, American Political Science Review, Vol.86, No.3, pp.658674.

Huber, Evelyne and Stephens, John (2001), Development and Crisis of the Welfare State: Parties and Policies in Global Markets. Chicago: University of Chicago Press. Jessop, Bob (2002), The Future of the Capitalist State. Cambridge: Polity.

Jobert, Bruno and Muller, Pierre (1987), L'E'tat en action. Politiques publiques et corporatismes. Paris: PUF.

Jones, R.J. Barry (1995), Globalisation and Interdependence in the International Political Economy. London: Pinter Publishers.

Keating, Michael (1998), The New Regionalism in Western Europe. Territorial Restructuring and Political Change. Cheltenham: Edward Elgar.

Kuhn, Thomas (1970), The Structure of Scientific Revolutions. Chicago, IL: Chicago University Press.

Kuhnle, Stein (ed.) (2000), The Survival of the European Welfare State, London/New York: Routledge. Lewis, Jane (1997), Gender and Welfare Regimes: Further Thoughts, Social Politics, Vol.4, No.2, pp.160-177.

Loughlin, John (2004), The "Transformation" of Governance: New Directions in Policy and Politics, Australian Journal of Politics and History, Vol.50, No.1, pp.8-22.

McEwen, Nicola and Moreno, Luis (eds) (2005), The Territorial Politics of Welfare. London/New York: Routledge.

Mishra, Ramesh (1999), Globalisation and the Welfare State. Cheltenham: Edward Elgar.

Moreno, Luis (2003), Europeanization, mesogovernments and safety nets, European Journal of Political Research, Vol.42, No.2, pp.185-199.

Moreno, Luis (2005), Multiple identities and global meso-communities, in Lachapelle, Guy and Paquin, Ste'phane (eds), Mastering Globalisation. New Sub-States' Governance and Strategies, pp.127-140. London/New York: Routledge.

Moreno, Luis and McEwen, Nicola (2005), Exploring the territorial politics of welfare, in Nicola McEwen and Luis Moreno (eds), The Territorial Politics of Welfare, pp.1-40. London/New York: Routledge.

Moreno, Luis and Palier, Bruno (2005), The Europeanization of Welfare: Paradigm shifts and social policy reforms, in Peter Taylor-Gooby (ed.), Ideas and Welfare State Reform in Western Europe, pp.145-175. Basingstoke: Palgrave Macmillan.

Peterson, Paul (1995), The Price of Federalism. Washington, D.C.: Brookings Institution. 
Pierson, Paul (ed.) (2001), The New Politics of the Welfare State. Oxford, Oxford University Press.

Piven, Frances (1995), Is it global economics or neo-laissez-faire?, New Left Review, No.213, pp.107-114. Regleg (2007), Declaration on behalf of the Interregional Group "Regions with Legislative Powers" in the CoR to the European Council on 21 and 22 June 2007. Available at http://www.cor.europa.eu/ document/Highlight/regleg_07062007.pdf (accessed 30 July 2007).

Rhodes, Martin (1996), Globalisation, the state and the restructuring of regional economies, in Philip Gummett (ed.), Globalisation and Public Policy, pp.161-180. Cheltenham: Edward Elgar.

Rodden, Jonathan (2003), Reviving Leviathan: fiscal federalism and the growth of government, International Organisation, Vol.57, No.4, pp.695- 729.

Schmidt, Vivien (1995), The New World Order, Incorporated. The Rise of Business and the Decline of the Nation-State", Daedalus, Vol.124, No.2, pp.75-106.

Strange, Susan (1995), The Retreat of the State. Cambridge, Cambridge University Press.

Surel, Yves (2000), The role of cognitive and normative frames in policy-making, Journal of European Public Policy, Vol.7, No.4, pp.495-512.

Svallfors, Stefan and Taylor-Gooby, Peter (eds) (1999), End of the Welfare State? The Responses to State Retrenchment: Evidence from Attitude Surveys. London/New York: Routledge. Swank, Duane (2002), Global Capital, Political Institutions and Political Change in Developed Welfare States. Cambridge: Cambridge University Press.

Taylor-Gooby, Peter (2002), The silver age of the welfare state: perspectives on resilience, Journal of Social Policy, Vol.31, No.4, pp.597-621.

Taylor-Gooby, Peter (2005), New Risks and Social Change, in Peter Taylor-Gooby (ed.), New Risks, New Welfare. The Transformation of the European Welfare State, pp.1-22. Oxford: Oxford University Press.

van Oorschot, Wim (2002), Popular Support for Social Security. A sociological perspective, in Jochen Clasen (ed.), What Future for Social Security? Debates and reforms in national and cross-national perspective, pp.33-52. Bristol: The Policy Press.

Weissert, Carol and Weissert, William (2002), Governing Health: The Politics of Health Policy. Baltimore: Johns Hopkins University Press. 